\title{
Article \\ "Likes" for Peace: Can Facebook Promote Dialogue in the Israeli-Palestinian Conflict?
}

\author{
Yifat Mor *, Yiftach Ron and Ifat Maoz \\ Department of Communication, Hebrew University of Jerusalem, Mount Scopus, Jerusalem, 91905, Israel; \\ E-Mails: yifat.mor1@mail.huji.ac.il (Y.M.), yiftach.ron@mail.huji.ac.il (Y.R.), msifat@mscc.huji.ac.il (I.M.) \\ * Corresponding author
}

Submitted: 19 April 2015 | Accepted: 5 October 2015 | Published: 18 February 2016

\begin{abstract}
This study examines the ways in which social media is used to promote intergroup dialogue and reconciliation in the context of the protracted, ethnopolitical conflict between Israeli-Jews and Palestinians. We focus on content analysis of posts and comments on a Facebook page named "Tweeting Arabs" which was established and is administered by Palestinian citizens of Israel. This page states that its' main goal is to publicize opinions, thoughts and beliefs of Palestinians, enabling the moderate voice to be heard and encouraging dialogue between Israeli-Jews and Palestinians. The analysis is based on a data set containing posts and comments collected from "Tweeting Arabs" since the page was founded in November 8th 2014 and until December 4th 2014. This data set contains 85 posts which gained a total of 9657 "likes", and 461 "shares", as well as 3565 comments and replies to these posts. Our findings reveal that while posts that presented the narrative of Palestinian suffering were mostly followed by negative comments from Israeli-Jews, posts that brought up the Palestinian moderate and peace seeking voice elicited higher Jewish-Israeli acceptance and sympathy. The research adds to our understanding of Facebook as a dialogue provoking platform that enables users from different ethnopolitical groups in divided and conflicted societies to perform peacebuilding actions.
\end{abstract}

\section{Keywords}

contact theory; intergroup dialogue; narrative model; peacebuilding; reconciliation; social media

\section{Issue}

This article is part of the issue "Peacebuilding in the Age of New Media", edited by Vladimir Bratic (Hollins University, USA).

(C) 2016 by the authors; licensee Cogitatio (Lisbon, Portugal). This article is licensed under a Creative Commons Attribution 4.0 International License (CC BY).

\section{Introduction}

Facebook serves as a main arena for public debate for Israelis, who are found to spend more time than any other nation on Facebook (McHugh, 2011; Mor, KliglerVilenchik, \& Maoz, 2015). During the second week of April 2015, 61,493 new Facebook friendships were formed between Israelis and Palestinians. ${ }^{1}$ And so, while remaining in a protracted ethnopolitical and intractable conflict which is perceived as irresolvable, Israeli-Jews and Palestinians interact on Facebook daily.

Intractable conflicts, such as the Israeli-Palestinian conflict, are a major force shaping the ethos and view-

${ }_{1}^{1}$ Peace.facebook.com points of the societies involved (Bar-Tal, 2007, 2013; Bar-Tal, Rosen, \& Nets-Zehngut, 2009; Kriesberg, 1998; Salomon, 2004). Intergroup dialogues are extensively used as mechanisms for reducing prejudice and improving relations between Israeli-Jews and Palestinians. However, only limited research attention has been dedicated to online dialogues as venues for IsraeliPalestinian peacebuilding and reconciliation (see Ellis \& Maoz, 2007; Hasler \& Amichai-Hamburger, 2013; Walther, Hoter, Ganayem, \& Shonfeld, 2014). Our study examines Facebook as a platform for promoting intergroup dialogues aimed at cooperation and reconciliation in the context of this protracted, ethnopolitical conflict between Israeli-Jews and Palestinians. It is based on a qualitative content analysis of posts and 
comments on a Facebook page named "Tweeting Arabs" which was founded and is administered by several Palestinian citizens of Israel. This page states that its main goal is to publicize opinions, thoughts and beliefs of Palestinians, enabling the moderate voice, seeking peace and justice, to be heard, and encouraging dialogue between Israeli-Jews and Palestinians. In light of the frequent use of Facebook in Israel and the sizable amount of interactions that are conducted between Israeli-Jews and Palestinians through this platform, this study examines mechanisms through which the "Tweeting Arabs" Facebook page attempts to promote the expression of reconciliatory voices, draws the Jewish-Israeli public into dialogue and attempts to build intergroup solidarity and civil understanding between Israeli-Jews and Palestinians.

\section{Theoretical Background}

Maoz (2004) defines two main characteristics of the sociopolitical context of the conflict between IsraeliJews and Palestinians, which are particularly relevant to reconciliation-aimed dialogue and peacebuilding efforts between the two sides: 1 . Relationships of conflict and aggression alongside coexistence and cooperation. 2. Inequality in which Israeli Jews have greater access to resources and influence over the culture, religion and language of the State. Thus, like other intergroup contact interventions conducted in settings of ethnopolitical conflicts, intergroup dialogue between Israeli Jews and Palestinians constitute a paradoxical project that aims to bring about open communication, equality and cooperation between two groups embedded in a deep-rooted reality of protracted conflict and asymmetry (Halabi, Sonnenschein, \& Friedman, 2004; Maoz, 2000a, 2000b, 2004, 2009, 2011; Ron \& Maoz, 2013a, 2013b; Suleiman, 2004a).

\subsection{Intergroup Dialogue between Israeli Jews and Palestinians}

Intergroup contact is commonly used as a device for grassroots level peacebuilding. Of all the interventions that have been designed for the reduction of intergroup bias and hostility, intergroup contact has seen the widest application and has been the one most commonly studied (Al Ramiah \& Hewstone, 2013; Pettigrew \& Tropp, 2006, 2011). The starting point for most theoretical reviews of intergroup contact is the Contact Hypothesis (Allport, 1954), which assumes that intergroup contact is likely to reduce stereotypes under the following four conditions: 1 . Equal status for the groups participating in the contact framework. 2. Contact based on common goals and on the existence of intergroup cooperation in order to achieve them. 3 . Opportunities for personal acquaintance through close and long-term contact. 4. Social and institutional sup- port for the intergroup contact. Other researchers have defined additional conditions for successful intergroup contact, such as a common language, voluntary participation, contact that is pleasant and beneficial, appropriate economic conditions, a not overly negative attitude toward the outgroup, etc. (Abu-Nimer, 1999; Dixon, Durrheim, \& Tredoux, 2005, 2007; Pettigrew, 1998; Ron, Maoz, \& Bekerman, 2010; Stephan \& Stephan, 2001).

Most of the empirical studies that have examined the effect of intergroup contact on reducing prejudices have noted the success of contact that takes place under conditions specified by the original Contact Hypothesis, even in cases where not all of the conditions are fully met (Al Ramiah \& Hewstone, 2013; Maoz, 2000a, 2000b; Pettigrew \& Tropp, 2006, 2011). At the same time, there has also been criticism of the limitations of the Contact Hypothesis regarding, among other things, the ability to sustain the contact effect also in situations of escalation of the intergroup conflict; and the ability of the contact model to deal effectively with interethnic tensions and asymmetric power relationships (Bekerman, 2002, 2009; Dixon et al., 2005, 2007; Maoz, 2000a, 2000b, 2011; Ron et al., 2010; Saguy \& Dovidio, 2013; Suleiman, 2004a, 2004b).

In view of the limitations of the Contact Hypothesis, alternative approaches to intergroup contact have developed. Maoz (2011) differentiates between four contact models: the Coexistence Model focuses on interpersonal contact aimed at promoting understanding and tolerance and at reducing prejudice, with emphasis on what is similar and shared (Allport, 1954; Pettigrew, 1998; Stephan \& Stephan, 2001). The Joint Projects Model is based on the assumption that a shared task which is directed toward achieving a common goal that is relevant to both sides will bring the sides closer together and create a shared superordinate identity (Campbell, 1965; Nadler, 2004; Sherif, 1966; Sherif, Harvey, White, Hood, \& Sherif, 1961). The Confrontational Model emphasizes the conflict and the asymmetric power relations between the sides, focusing on group and national identities (Tajfel \& Turner, 1979, 1986). Finally, the Narrative Model is based on story telling (Bar-On, 2006, 2009; Bar-On \& Kassem, 2004), and on approaches that focus on promoting recognition and legitimization of the collective narrative of the other (Adwan \& Bar-On, 2004; Bar-On, 2006, 2009; Bar-On \& Adwan, 2006; Salomon, 2004).

\subsection{The Narrative Model of Intergroup Dialogue}

The Narrative Model is particularly relevant to this article's attempt to reveal mechanisms through which a social media platform promotes the expression of reconciliatory voices of Palestinians and exposes IsraeliJews to these voices. The narrative approach to intergroup contact has begun to develop in the 1990's and 
early 2000's against the background of increased attention to the centrality of narratives as an organizing feature of social and cultural life (Bruner, 2008; Hammack, 2009; Hammack \& Pilecki, 2012) and to the importance of cognitive and affective intergroup processes such as the reduction of intergroup threat and empathizing with the suffering of the other (Stephan, 2008, 2014). The model is identified with the theoretical approach of intergroup reconciliation proposed by Salomon (2004), and to a greater extent-with the theory and practice offered by the late Israeli psychologist, Dan Bar-On (2006, 2008, 2009; Bar-On \& Kassem, 2004).

Salomon (2004) claims that the collective narratives of groups in conflict and their implied delegitimization of the out-group's narrative should be the main target for change when promoting intergroup reconciliation. To this end he proposed an educational process focusing on the exposure, recognition and legitimization of the narrative of the other (Salomon, 2004). Bar-On's theoretical approach to encounter and dialogue between conflicting narratives relies on the assumption that in order to reach reconciliation, ethnic or national groups in protracted conflict must work through their unresolved anger and pain through story-telling. Encountering the experience and suffering of the other through story-telling is seen as enabling conflicting groups to create compassion and intergroup trust by re-humanizing and constructing a more complex image of each other (Bar-On, 2006, 2008, 2009; Maoz \& BarOn, 2002; Ron \& Maoz, 2013a). It is argued that the exposure to multiple stories about the lives of others in the conflict has the potential to increase one's understanding of the complexities of one's own group on the one hand, and of the other group's personal and collective trajectories in the conflict on the other (Bar-On 2006, 2009; Bar-On \& Kassem, 2004).

The narrative approach acknowledges the central role played by collective and personal narratives in maintaining protracted ethnopolitical conflicts, and hence, the need to cope with the deep-rooted narratives of conflict, and to expose each side to the narrative of the other through processes of intergroup dialogue. In a study that explores the effects of continuous long-term exposure to the contesting narrative of the outgroup in the context of the protracted conflict between Israelis and Palestinians, Ron and Maoz (2013a) point to the ways in which intergroup dialogue encounters enable the Jewish participants to better understand the narrative, the sufferings and emotions of their Palestinian counterparts, and to undergo a process of moral inclusion of the Palestinian other. This leads many of the Jewish participants to later take an active role in alternative frameworks of action, such as academic research, education for peace, and activism in civil society organizations.

The findings of Ron and Maoz point to the potential of intergroup dialogue to help cope with the negative role played by narratives in protracted ethnopolitical conflicts and to promote peacebuilding and intergroup reconciliation (2013a). Amichai-Hamburger and Mckenna (2006) point to the benefits of the Internet as a protected environment for users and as a medium for intergroup communication and contact. The purpose of the present study is to examine the ways in which social media may be used to promote reconciliationaimed dialogue in general, and the narrative model of intergroup dialogue in particular, in the context of the protracted, ethnopolitical conflict between Israeli-Jews and Palestinians.

\subsection{Computer Mediated Dialogues in the Israeli-Palestinian Conflict}

Due to the intractable conflict between Israeli-Jews and Palestinians, and the severity of the violence and security issues it involves, face-to-face (FTF) contact between representatives of the two groups may be hard to arrange. Thus, computer mediated communication (CMC) may become a highly relevant alternative for conducting dialogue between the groups (Ellis \& Maoz, 2007).

Both CMC and FTF communication have their advantages and disadvantages, yet $\mathrm{CMC}$ has lately become a highly important platform, paving the way for new social and communicative horizons. Online discussions can play an important role in constructing a public sphere in which the transformation and remaking of attitudes and practices can occur (de-Vries, Simri, \& Maoz, 2015; Ellis \& Maoz, 2007; Hasler \& AmichaiHamburger, 2013; Maoz \& Ellis, 2006; Mor et. al., 2015; Walther et al., 2014). Facebook discussions are described in several studies as "Eco Chambers": as interactions that are conducted in homogenous clusters in which users interact with other like-minded users (see for example John \& Dvir, 2015). Ellis and Maoz (2007) researched argument patterns in online group discussions between Jewish-Israeli and Palestinian youth. Their findings indicate that unlike in FTF intergroup discussions, Israeli-Jewish and Palestinian participants did not develop structured and complex arguments through $\mathrm{CMC}$ but rather exchanged unelaborated expressions of disagreement over points of view or over the right to have various points-of-view and tended to regress to a cycle of dead-end arguments.

Hasler and Amichai-Hamburger (2013) suggested in their review on online intergroup contact that further research should explore the extent to which there is a relationship between the discussed topics and the generation of a positive and cooperative intergroup interaction. Previous empirical research reveals that online interactions focusing on the topics of Jewish and Islamic religious practices or collaborative learning, generated a positive sphere for dialogue (Mollov, 2006). However, online interactions focusing on issues related to 
the asymmetrical, ongoing political and social conflict did not decrease the hostility between the groups (Hasler \& Amichai-Hamburger, 2013; Hoter, Shonfeld, \& Ganayim, 2009; Walther et al., 2014). Our study continues this previous research and further explores the extent to which the topic of a discussion conducted through a Facebook page is associated with the nature of the intergroup dialogue that develops between Israeli Jews and Palestinians.

Facebook presents itself as a platform through which unexpected friendships occur. A unique Facebook feature called 'World of friends' displays the number of new Facebook friendships formed each week between Israelis and Palestinians. ${ }^{2}$ According to these reports, during the second week of April 2015, 61,493 new Facebook friendships have formed between Israelis and Palestinians. ${ }^{3}$

Given this documented sizable volume of intergroup Facebook friendships it is important to further understand the factors that affect the extent to which these interactions, conducted in the context of an intractable protracted conflict, can be constructive and cooperative. Our study focuses on a Facebook page aimed at encouraging intergroup dialogue, and explores the ways in which this Facebook platform is used to promote reconciliation and peacebuilding between Israeli-Jews and Palestinians.

\section{Method}

\subsection{Research Corpus}

The analysis focuses on a Facebook page founded and administrated by Palestinian citizens of Israel in November 2014, under the name "Tweeting Arabs". The page's declared mission is to expose Israeli-Jews to Palestinian narratives and perspectives by publishing personal stories, peace-seeking expressions, massmedia criticism and more. Consequently, the page aims to attract as many Israeli-Jewish followers as possible in order to communicate the Palestinian narrative and enable an open dialogue. The posts published by the page admins are solely in Hebrew, and so are most of the discussions following these posts, in which both Israeli-Jews and Palestinians take part. The page is followed by approximately 7000 Facebook users ${ }^{4}$.

The decision to focus on this particular Facebook page was based on an initial mapping of Facebook pages which host dialogue between Israeli-Jews and Palestinians. Except for "Tweeting Arabs", all the Facebook

\footnotetext{
2 Peace.facebook.com

3 Peace.facebook.com

${ }^{4}$ Retrieved on April 2015 from https://www.facebook.com/ pages/\%D7\%A2\%D7\%A8\%D7\%91\%D7\%99\%D7\%9D\%D7\%9E\%D7\%A6\%D7\%99\%D7\%99\%D7\%A6\%D7\%99\%D7\%9D/ 984026594946799?sk=likes
}

pages we explored had 4,000 followers or less. Since the page "Tweeting Arabs" was significantly more popular than the other pages mapped, we chose to focus our study on this page.

We examined posts that were published between November 8th 2014 and December 4th of the same year, following the 2014 Israel-Gaza conflict (JulyAugust 2014), and prior to the 2015 elections in Israel. Both events increased the tension between Israeli-Jews and Palestinians placing intergroup violence and prejudice in the center of the public debate in Israel, particularly on Facebook. The analysis is based on 85 posts that gained a total of 9657 "likes" and 461 "shares". The 3565 comments and replies that followed these posts are analyzed as well.

\subsection{Method of Analysis}

Our analysis is inspired by the Grounded Theory approach (Glaser \& Strauss, 1967), which emphasizes the construction of theories and concepts based on data that was gathered in the research process (Strauss \& Corbin, 1998). In line with this paradigm (Berg, 2004; Strauss \& Corbin, 1998) we conducted a horizontal reading of the Facebook page posts in order to identify relevant main themes. The units of analysis were the posts, including attached pictures, articles and texts. Several more readings led us to narrow down the number of themes identified in the first stage by merging similar categories and focusing on the ones that have been found common, interesting and relevant to our work. Finally, posts - together with the comments and replies that followed them-were categorized according to the themes. The two major themes derived from the analysis are presented in the following Findings section.

\section{Findings}

The section below presents two major themes that emerge from our analysis of the posts and related comments and responses that appeared on the "Tweeting Arabs" Facebook page.

\subsection{Posts Presenting the Palestinian Narrative in the Conflict and Jewish-Israeli Responses}

According to Ron and Maoz (2013a), exposure to the Palestinian narrative in the conflict may undermine Israeli-Jews' own narrative or even unsettle their identity and moral self-conception-resulting in expressions of sympathy, guilt and regret towards Palestinians. However, in our study we find that posts expressing the Palestinian perspective on the conflict provoked mostly negative comments from Israeli-Jews, including blaming the Palestinians for hypocrisy. A post published by the page admins on December 3,2014, shows a picture 
of the IDF demolishing a Palestinian building in the West Bank, explaining that the demolition was done in order to expand an Israeli checkpoint. This post gained 50 "likes" and was followed by negative comments from Israeli-Jews such as the following:

"Thank God. Any illegal building should be destroyed, especially when it concerns Israeli citizens' security. No one cries over the demolition of houses in Jewish settlements."

Moreover, several Israeli-Jews stated that buildings are being demolished in Egypt too; suggesting that showing only the damage done by the IDF is hypocritical:

"Do you understand now why the Jews see the Palestinians and the world as hypocrites??? When you only focus on the Jews, it is called hypocrisy and anti-Semitism."

Another Israeli-Jew wrote in response to the same post:

"There are other Arabs too. A very small minority that is loyal to the state. But to find them is like looking for a needle in a haystack."

These comments were followed by additional comments by one Israeli-Jew commenter containing links to Israeli-Jewish press coverage of violent incidents and terror attack attempts in which Palestinians have recently been involved.

Apparently, the exposure to the Palestinian point of view on the conflict and to the suffering of the Palestinians provoked antagonism among Israeli-Jewish commenters, and led them to suggest an alternative perspective on the described Israeli action (demolishing houses of Palestinians) that puts the blame on Palestinians. A more varied array of Jewish-Israeli responses was elicited by another post published by the Palestinian admins of "Tweeting Arabs" on November 26,2014 . This post brought a picture of children in Gaza walking in the rain to school and gained 227 "likes". The picture portrays young children walking through flooded roads due to the lack of infrastructure. The accompanying text says:

"The way from the non-existing home to what used to be a school, winter in Gaza"

The comments to this post vary; some Israeli-Jews sympathized with the message, yet blamed the situation on Hamas and on those who voted for them:

"Sad picture. Sad life. No hope, no dreams. Let's hope the parents and adults of these sweet children will go out to the streets in order to change the future for the next generation in Gaza."
Another comment by an Israeli-Jew stated:

"Billions were raised for rebuilding Gaza, where did the money go?"

This comment was followed by a discussion in which Palestinians claimed that the money never made its way to Gaza. One of these commenters wrote:

"It's not only sad my dear, it is shocking and horrifying and inconceivable. I have a family there and they've sent me a picture that is disappointing, troubling. No matter that she's Palestinian, no matter what you'll say, this picture runs shivers through your body. A woman, maybe 56 years old, drinking water from the road and it's not only sad, unfortunately, it's disheartening."

In some of the replies to this comment, Israeli-Jews showed sympathy:

“I don't understand the comments here. Nobody mentioned Hamas or Israel, these kids are the victims of a war!!! Put politics aside and be human for a moment"

However, most Israeli-Jew commenters stated again that although the people of Gaza deserve better, they should turn against Hamas which is to blame for their situation. These commenters made one Palestinian commenter very upset:

"Most of the comments here are inhuman!!! Thus I'm not surprised it makes normal people turn radical..... Instead of reconciling you do the opposite and turn people away from you.... These children aren't to blame for anything except being born there!!! And if it was the other way around and these were comments made by Palestinians you would curse them, calling them barbarians and animals....But you can see who is being a barbarian and inhuman....And everyone who commented here with cruelty is no different than Hamas."

The above quotes reveal that Israeli-Jews find it hard to accept the narrative of Palestinian pain and suffering and tend to respond negatively to Palestinian posts that express these themes. While a picture of a building being demolished by the IDF aroused mostly negative comments from Israeli-Jews, a picture of suffering Palestinian children did bring about some sympathetic Israeli-Jewish reactions. Nevertheless in both cases, some Israeli-Jew commenters perceived the expression of Palestinian suffering as an allocation of blame on Israel, resulting in defensive reactions. Apparently, unlike in previous research on dialogue groups conducted offline, when the dialogue takes place online, in 
an open platform such as Facebook, the narrative of the Palestinian suffering may bring about sympathy from the Israeli-Jewish participants but may also cause antagonism and result in a clash of narratives and arguments between Israeli-Jews and Palestinians.

\subsection{Responses Calling for Peace and Reconciliation: Palestinian Posts and Jewish-Israeli Responses}

Another major theme that emerged from our analysis of posts and comments concerns a Palestinian attempt to display a contradicting message to the one commonly presented in the Israeli press: a message that brings the Palestinian voice supporting peace and condemning terror.

The protracted, ethnopolitical conflict between Israeli-Jews and Palestinians is characterized by inequality in which Israeli-Jews have greater access to resources (Maoz, 2004). Within this context of asymmetric power relations, Wolfsfeld, Avraham and Aburaiya (2000) discuss the biased representation of Palestinian activism, protests and demands from the Israeli government in Israeli-Hebrew press. According to Wolfsfeld and his colleagues, the Israeli mass media tends to exaggerate threats of violence posed by protests, thus, instead of constituting a resource for minority groups and allowing social mobility, the press serves as an agent preventing such change (2000). Internet use may transform these dynamics and allow other voices to be heard (Castells, 2013; Loader \& Mercea, 2011). The internet makes it easier to access large amounts of information from various sources (Hasler \& Amichai-Hamburger, 2013). Specifically, Facebook proudly states that it connects people from all over the world even in unexpected places, announcing on new friendships that are created weekly through this platform between Israelis and Palestinians. ${ }^{5}$ During the time of our study, there were several incidents in which Palestinians attacked or attempted to attack Israelis. These incidents were strongly condemned by the Palestinian page admins, as shown in a post they published on December 3, 2014, and that gained 110 "likes". The post relates to an incident of a Palestinian attacker who stabbed two Jewish citizens in a supermarket:

"As long as we won't learn how to condemn all sorts of violence, including the attempt to attack the innocents in order to kill.....As long as we won't be able to teach ourselves what is a legitimate struggle and what is a low and damned act of sabotage.... Until then we will carry on suffering for losing our way and losing our moral compass."

Jewish Israeli responses to this post were often very positive. One response stated that incidents in which Jewish settlers stabbed Palestinians should be similarly condemned, and another stated that the Israeli response to the Palestinian stabbing was too violent and only contributed to the circle of bloodshed. On the other hand, one Israeli-Jewish user claimed that most of the "likes" on the post came from profiles of IsraeliJews and thus the support for the Palestinian condemnation of the violent incident does not represent the majority of Palestinian citizens of Israel. Yet, the majority of Israeli-Jews' responses to this condemnation were positive, suggesting that generally, the message of Palestinians condemning terror was appealing to Israeli-Jews. For example:

"What a Facebook page, pleasant to the eyes and to the heart....Keep it up! There is no other Facebook page like yours - full of peace and truth. I wish everyone would think the same-then our world would look much brighter."

In another post that was published by the page admins on November 27, and that gained 368 "likes", a photo of an IDF soldier dressing the wound of a Palestinian child was followed by the text:

"The truth isn't always popular...sometimes the truth hides between the lines."

The responses to this post varied between positive and negative comments from both sides. The positive comments reflected appreciation for the soldier and his humanitarian act. For example, one Palestinian wrote:

"Every person is partially good and partially bad. His being a soldier does not imply that he doesn't have a kind heart. He is just doing his job, nevertheless he is a very compassionate person. I really liked it"

Other comments-such as the one here below that was posted by an Israeli-Jew-blamed the press for the mutual hatred and emphasized that the people can live together in peace:

"I don't feel any hatred towards Palestinians. A person is first of all a person and is to be judged according to his deeds. Leave the internet, the television, the poisoned news and come and make new Jewish friends. Maybe together we'll create a better future"

However, Some Israeli-Jewish and Palestinian users claimed that if it wasn't for the IDF activity in the territories, the child would never have gotten hurt in the first place. One Israeli-Jewish commenter wrote:

${ }^{5}$ Peace.facebook.com 
"It's only human...he shot a rubber bullet to the kid's head and now he's dressing his wound because the army of peace, 'Betzelem' (an Israeli peace organization, documenting the IDF activity in Gaza and the territories, Y.M.), is taking pictures nearby"

Yet, other Israeli-Jews commented that this child will grow up to be a terrorist and the soldier should not have saved him:

"He'll grow up and become a terrorist"

It appears, thus, that the intergroup dialogue generated by the posts published on "Tweeting Arabs" enables the expression of different and diverse voices and opinions that include sympathy to the other side, criticism of one's own side as well as blaming the other side.

Another post that was published by the page admins on December 4, and gained 131 "likes" also elicited an array of responses that in this case did not include mutual blaming, but did include blaming the leadership on both sides. This post showed a banner with the words "The majority chose PEACE", coupled with this text:

"To violence and racism I refuse, we should reconcile and come together, let's talk about peace and coexistence, words connect hearts....Far from contempt, only reasonable thoughts.....t isn't hard to do....Eventually we'll find an answer....You have bought us with terror, but how much longer will we wait? Whoever dug a hole in the ground, will fall into it himself, me-l'm pure, l've praised the peace that will come. They said I'm drunk, it only strengthens my hope $(;)$

The above post was followed by positive comments from both Israeli-Jews and Palestinians. Some asserted that while ending the conflict may not be an easy thing to do, it is possible, like this comment from an IsraeliJewish user:

"For a better life in the Middle East, we must have peace. And for those who claim that it's impossible-peace is made between enemies, not between friends."

Others blamed the leadership on both sides for not wanting peace, like this Palestinian user:

"There will be no peace as long as the leaders from both sides make their profit out of war....Peace can come between the peasants maybe, those who live side by side....But the war will go on."

Interestingly, we find that the posts brought within our first theme, and that dealt with Palestinian suffering, led to discussions in which Israeli-Jews and Palestinians predominantly blamed one another for the situation. However, the posts brought within this second theme-that dealt with the Palestinian call for peace, elicited exchanges that were predominantly positive and a dialogue characterized by partnership and hope.

\section{Discussion}

Although intergroup contact and the role it plays in the reduction of prejudice and intergroup hostility is commonly studied (Al Ramiah \& Hewstone, 2013; Brown \& Hewstone, 2005; Pettigrew \& Tropp, 2006, 2011; Stephan, 2008, 2014), relatively little research attention has been devoted to the ways in which social media can be used to promote dialogue and reconciliation between conflicting national or ethnic groups (AmichaiHamburger \& Mckenna, 2006; Ellis \& Maoz, 2007; Hasler \& Amichai-Hamburger, 2013). The current study examines intergroup dialogue conducted online in the context of the protracted, ethnopolitical conflict between Israeli-Jews and Palestinians.

Our analysis of major themes, messages and responses that appeared in the Facebook page "Tweeting Arabs" revealed that while posts that presented the narrative of Palestinian suffering were mostly followed by negative comments from Israeli-Jews, posts that brought up the Palestinian moderate and peace seeking voice elicited higher Israeli-Jewish acceptance and sympathy.

More specifically, we found that the exposure to the Palestinian pain and suffering led to a predominantly negative intergroup exchange, characterized by mostly defensive Jewish-Israeli comments, suggesting that the fault for the suffering is of the Palestinians themselves and specifically of Hamas, for whom the Palestinian people voted in the governmental elections. On the other hand, the exposure to a moderate and peace seeking Palestinian voice facilitated a positive dialogue between Israeli-Jews and Palestinians, expressing hope, sympathy and acceptance. Here below we discuss these findings in light of relevant previous literature dealing with face-to-face and online intergroup contact and dialogue, while mostly focusing on the context of the Israeli-Palestinian conflict.

\subsection{The Narrative Approach to Intergroup Dialogue and the Exposure to the Palestinian Perspective through a Facebook Page Dialogue}

The narrative approach to intergroup dialogue in settings of protracted ethnopolitical conflict is based on the assumption that the exposure to multiple stories about the lives, the experiences and the suffering of the other in a conflict can enable conflicting groups to create intergroup trust and compassion by re- 
humanizing and constructing a more complex image of each other (Bar-On, 2006, 2008, 2009; Bar-On \& Kassem, 2004; Maoz \& Bar-On, 2002). In a research program that explored the effects of exposure to the contesting narrative of the outgroup in the context of the Israeli-Palestinian conflict, Ron and Maoz (2013a, 2013b; Ron et al., 2010) found that continuous involvement in intergroup face-to-face (off-line) dialogue-encounters enabled Jewish participants to better understand the narrative, the sufferings and emotions of their Palestinian counterparts, and to undergo a process of moral inclusion of the Palestinian other (Ron \& Maoz, 2013a). These processes led to ideological changes (Ron et al., 2010) and to more complex attitudes toward the resolution of the Israeli-Palestinian conflict (Ron \& Maoz, 2013b).

The picture that emerges from our findings regarding the Jewish-Palestinian dialogue conducted online through the platform of a Facebook page, is more ambiguous. In line with previous findings regarding faceto-face dialogues (Ron \& Maoz, 2013b), the exposure of Jewish Israeli Facebook-users to moderate, conciliatory or self-critical posts written by Palestinians evoked positive and sympathetic responses. However, Facebook posts dealing with Palestinian pain and suffering elicited sympathy in some cases but mostly led to defensive and negative Jewish-Israeli responses and to discussions in which both groups blamed one another for the situation.

These findings seemingly contradict previous studies demonstrating the strength of the Narrative Model face-to-face dialogues in eliciting intergroup understanding and sympathy (Bar-On, 2006, 2008; Ron \& Maoz, 2013a, 2013b). It should be noted, however, that the changes reported in the studies conducted by Ron and Maoz, for example, are attributed to the continuous and repeated involvement in dialogue-encounters over an extended period of time (Ron \& Maoz, 2013a, 2013b; Ron et al., 2010). It seems that such long-term process of exposure to the dialogue interaction and to the narrative of the Palestinian other, does not take place in the case examined in our present study.

\subsection{Dialogue as Process}

Qualitative studies addressing processes and interactions as they occur in face-to-face intergroup dialogue encounters, point to a complex and gradual process that takes place in these encounters. Maoz, Bar-On and their colleagues reveal the difficulties and challenges that are encountered in some of the sensitive dialogue processes between Israeli-Jews and Palestinians, and characterize these processes as ranging from "good enough" successful dialogues, to explosive, destructive ones, in which the difficulties are not successfully dealt with through the continuous intergroup dialogue (Maoz, Bar-On, Bekerman, \& Jaber-Massarwa, 2004;
Maoz, Bar-On \& Yikya, 2007). Steinberg and Bar-On (2002) describe the gradual process of dialogue and relationship building that occurs in face-to-face encounters between Israeli-Jews and Palestinians. This process typically begins with "Ethnocentric talk" in which the participants use argumentation, do not share their feelings, and in which the discussion tends to be based on simplistic perceptions of self and other; and gradually moves to "Dialogic moments", characterized by sharing feelings with others, listening and reacting in a non-judgmental way and trying to understand the other's point of view. The predominantly negative and defensive Israeli-Jewish response to expressions of Palestinian suffering in the conflict can be attributed to the lack of long-term process of dialogue and relationship building in the studied case of a dialogue conducted through the online platform of a Facebook page.

\subsection{Facebook Page as a Platform for Dialogues in the Israeli-Palestinian Conflict}

Facebook differs from other platforms for online dialogue in several ways. Unlike other online platforms, Facebook is a public arena with public-sphere characteristics in which the participants are not anonymous. Examining Facebook in Israel is highly important since Israelis are the heaviest internet users in the world and spend more time on Facebook than any other nation, thus rendering Facebook as a main arena for public debate (Karniel \& Lavie-Dinur, 2012; McHugh, 2011; Mor et. al., 2015).

Our study explored Israeli-Jews' reactions to two different topics that were discussed in the Facebook page posts presenting the Palestinian narrative and perspectives in the conflict: Palestinians' descriptions of their suffering in the conflict and Palestinians' call for peace and reconciliation. In line with the findings of Mollov (2006) and Hoter et al. (2009), our findings indicate that while exposure to Palestinian' descriptions of their suffering generally generated negative reactions from Israeli-Jews, exposure to Palestinians' call for peace generated predominantly positive reactions from the Israeli-Jewish commenters and enabled a dialogue characterized by partnership and hope. Thus our study indicates that when analyzing dead-end online intergroup dialogues such as the one documented by Ellis and Maoz (2007), it is important to take into account the nature of the topic discussed, together with the features of the online platform.

These finding are highly significant. In line with previous studies regarding both face-to-face dialogue as well as online dialogue between Israeli-Jews and Palestinians (Hasler \& Amichai-Hamburger, 2013; Maoz, 2000a, 2000b, 2011), our study points to the major role the topic of discussion may play in enabling cooperative dialogues between groups in protracted ethnopolitical conflicts. 
Our findings suggest that Facebook can indeed serve as a platform that enables intergroup dialogue in the context of the intractable conflict between Israelis and Palestinians. Facebook is an open arena for discussions, on which participants from different ethnopolitical groups in a conflicted society can share ideas, opinions and reactions (Mor et. al., 2015) and engage in peacebuilding activities. With approximately 7000 followers, that include both Israeli-Jews and Palestinians that hold diverse opinions and take part in the discussions voluntarily, "Tweeting Arabs", as well as similar Facebook pages and groups, can support and facilitate reconciliation aimed dialogue between Israeli-Jews and Palestinians.

\subsection{Limitations and Directions for Future Research}

Despite the importance of our findings to the understanding of Facebook as a dialogue facilitating platform that enables users from different ethnopolitical groups in divided and conflicted societies to perform peacebuilding actions, this study also has certain limitations. First, the research is based on data that were collected from one specific Facebook page and during a limited period of one month. Further research should examine data from several relevant Facebook pages and over an extended period of time in order to enable broader generalizations regarding the dynamics of peacebuilding through Facebook. Furthermore, although Facebook does make it easier for Israeli-Jews and Palestinians to communicate, it is important to also keep in mind those who are excluded from such dialogue due to language difficulties and lack of access to technology. Therefore, our findings cannot be automatically generalized to the entire Israeli Jewish and Palestinian population. It is thus important to also continue exploring alternative and potentially more inclusive platforms for intergroup contact aimed at peacebuilding.

\section{Conclusion}

It seems that at least in their current form online dialogues that take place on Facebook pages such as "Tweeting Arabs" lack the continuity that enables the dynamic development and building of intergroup relationship that characterizes some of the face-to-face dialogue encounters conducted offline (Ellis \& Maoz, 2007). Given the potentially non-continuous nature of intergroup communication through posts and comments published on the platform of a Facebook page, it may be worthwhile to consider adjusting the model of dialogue implemented online to the features and limitations of these types of interactions. The findings of our study indicate that the Coexistence Model of dialogue which focuses on promoting understanding and tolerance and emphasizes intergroup commonalities (Maoz, 2011), might be more effective as a model for an online peace- building dialogues than other, more complex approaches to intergroup dialogue such as the Confrontational or the Narrative approach (Maoz, 2011). These findings, thus, enable us to engage in careful optimism regarding the potential for a constructive, peacebuilding intergroup dialogue through social media platforms in settings of protracted ethnopolitical conflicts.

\section{Acknowledgments}

The authors thank the late Professor Gavriel Salomon, who dedicated much of his life work to the study and promotion of peace education. This article is inspired by his work and dedicated to his memory.

\section{Conflict of Interests}

The authors declare no conflict of interests.

\section{References}

Abu-Nimer, M. (1999). Dialogue, conflict resolution, and change: Arab-Jewish encounters in Israel. Albany, NY: State University of New York Press.

Adwan, S., \& Bar-On, D. (2004). Shared history project: A PRIME example of peacebuilding under fire. International Journal of Politics, Culture and Society, 17, 513-521.

Al Ramiah, A., \& Hewstone, M. (2013). Intergroup contact as a tool for reducing, resolving, and preventing intergroup conflict: Evidence, limitations and potential. American Psychologist, 68(7), 527-542.

Allport, G. W. (1954). The nature of prejudice. Reading MA: Addison-Wesley.

Amichai-Hamburger, Y., \& Mckenna, K. Y. A. (2006). The Contact Hypothesis reconsidered: Interacting via the Internet. Journal of Computer-Mediated Communication, 11(3), 825-843.

Bar-On, D. (2006). Tell your life-story: Creating dialogue between Jews and Germans, Israelis and Palestinians. Beer-Sheva: Ben-Gurion University in the Negev Press.

Bar-On, D. (2008). The others within us: Constructing Jewish-Israeli identity. New York: Cambridge University Press.

Bar-On, D. (2009). Storytelling and multiple narratives in conflict situations: From the TRT group in the German-Jewish context to the dual-narrative approach of PRIME. In G. Salomon \& E. Cairns (Eds.), Handbook on peace education (pp. 199-212). New York and Hove: Psychology Press.

Bar-On, D., \& Adwan, S. (2006). The psychology of better dialogue between two separate but interdependent narratives. In R. I. Rotberg (Ed.), Israeli and Palestinian narratives of conflict: History's double helix (pp. 205-224). Bloomington, IN: Indiana University Press. 
Bar-On, D., \& Kassem, F. (2004). Storytelling as a way to work through intractable conflicts: The GermanJewish experience and its relevance to the Palestinian-Israeli context. Journal of Social Issues, 60(2), 289-306.

Bar-Tal, D. (2007). Sociopsychological foundations of intractable conflicts. American Behavioral Scientist, 50, 1430-1453.

Bar-Tal, D. (2013). Intractable conflicts: Sociopsychological foundations and dynamics. Cambridge: Cambridge University Press.

Bar-Tal, D., Rosen, Y., \& Nets-Zehngut, R. (2009). Peace education in societies involved in intractable conflicts: Goals, conditions, and directions. In G. Salomon. \& E. Cairns (Eds.), Handbook on peace education (pp. 21-43). New York and Hove: Psychology Press.

Bekerman, Z. (2002). The discourse of nation and culture: Its impact on Palestinian-Jewish encounters in Israel. Peace and conflict: Journal of Peace Psychology, 8(3), 259-276.

Bekerman, Z. (2009). Identity work in PalestinianJewish intergroup encounters: A cultural rhetorical analysis. Journal of Multicultural Discourse, 4(2), 205-219.

Berg, B. L. (2004). Qualitative research methods for the social sciences. Boston MA: Pearson.

Brown, R., \& Hewstone, M. (2005). An integrative theory of intergroup contact. Advances in Experimental Social Psychology, 37, 255-343.

Bruner, J. (2008). Culture and mind: Their fruitful incommensurability. Ethos, 36(1), 29-45.

Campbell, D. T. (1965). Ethnocentric and Other Altruistic Motives. In D. Levine (Ed.), Nebraske Symposium on Motivation (pp. 283-311). Lincoln,NE: University of Nebraska Press.

Castells, M. (2013). Communication power. Oxford University Press.

de-Vries, M., Simri, A., \& Maoz, I. (2015). Like a bridge over troubled water: Using Facebook to mobilize solidarity among East Jerusalem Palestinians during the 2014 war in Gaza. International Journal of Communication, 9, 2622-2249.

Dixon, J., Durrheim, K., \& Tredoux, C. (2005). Beyond the optimal contact strategy: A reality check for the contact hypothesis. American Psychologist, 60(7), 697-711.

Dixon, J., Durrheim, K., \& Tredoux, C. (2007). Intergroup contact and attitudes toward the principle and practice of racial equality. Psychological Science, 18(10), 867-872.

Ellis, D. G., \& Maoz, I. (2007). Online argument between Israeli Jews and Palestinians. Human Communication Research, 33(3), 291-309.

Glaser, B. G., \& Strauss, A. L. (1967). The discovery of grounded theory: strategies for qualitative research. Chicago, IL: Aldine Publishing Co.
Halabi, R., Sonnenschein, N., \& Friedman, A. (2004). Liberate the oppressed and their oppressors: Encounters between university students. In R. Halabi (Ed.), Israeli and Palestinian identities in dialogue: The school for Peace approach (pp. 59-78). New Brunswick, NJ: Rutgers University Press.

Hammack, P. L. (2009). Exploring the reproduction of conflict through narrative: Israeli youth motivated to participate in a coexistence program. Peace and Conflict: Journal of Peace Psychology, 15, 49-74.

Hammack, P. L., \& Pilecki, A. (2012). Narrative as a root metaphor for political psychology. Political Psychology, 33(1), 75-103.

Hasler, B. S., \& Amichai-Hamburger, Y. (2013). Online intergroup contact. In Y. Amichai-Hamburger (Ed.), The social net: Understanding our online behavior (pp. 220-252). New York: Oxford University Press.

Hoter, E., Shonfeld, M., \& Ganayim, A. (2009). Information and communication technology (ICT) in the service of multiculturalism. The International Review of Research in Open and Distributed Learning, 10(2). Retrieved from http://www.irrodl.org/ index.php/irrodl/article/view/601/1207

John, N. A., \& Dvir-Gvirsman, S. (2015). “I don't like you anymore": Facebook unfriending by Israelis during the Israel-Gaza conflict of 2014. Journal of Communication, 65(6), 953-974.

Karniel, Y., \& Lavie-Dinur, A. (2012). Privacy in new media in Israel: How social networks are helping to shape the perception of privacy in Israeli society. Journal of Information, Communication and Ethics in Society, 10(4), 288-304.

Kriesberg, L. (1998). Intractable conflicts. In E. Weiner (Ed.), The handbook of interethnic coexistence (pp. 333-342). New York: Continuum.

Loader, B. D., \& Mercea, D. (2011). Networking democracy? Social media innovations and participatory politics. Information, Communication \& Society, 14(6), 757-769.

Maoz, I. (2000a). Multiple conflicts and competing agendas: A framework for conceptualizing structured encounters between groups in conflict-The case of a coexistence project of Jews and Palestinians in Israel. Journal of Peace Psychology, 6(2), 135-156.

Maoz, I. (2000b). Power relations in intergroup encounters: A case study of Jewish-Arab encounters in Israel. International Journal of Intercultural Relations, 24, 259-277.

Maoz, I. (2004). Coexistence is in the eye of the beholder: Evaluating intergroup encounter interventions between Jews and Arabs in Israel. Journal of Social Issues, 60(2), 437-452.

Maoz, I. (2009). Educating for peace through planned encounters between Jews and Arabs in Israel: A reappraisal of effectiveness. In G. Salomon \& E. Cairns (Eds.), Handbook on peace education (pp. 303-313). New York and Hove: Psychology Press. 
Maoz, I. (2011). Does contact work in protracted asymmetrical conflict? Appraising 20 years of reconciliation-aimed encounters between Israeli Jews and Palestinians. Journal of Peace Research, 48(1), 115-125.

Maoz, I., \& Bar-On, D. (2002). The link from working through the Holocaust to current ethnic conflicts: Describing and evaluating the TRT group workshop in Hamburg. Group, 26, 29-48.

Maoz, I., Bar-On, D., Bekerman, Z., \& Jaber-Massarawa, S. (2004). Learning about 'good enough' through 'bad enough': A story of a planned dialogue between Israeli Jews and Palestinians. Human Relations, 57(9), 1075-1101.

Maoz, I., Bar-On, D., \& Yikya, S. (2007). "They understand only force": A critical examination of the eruption of verbal violence in a Jewish-Palestinian dialogue. Peace and Conflict Studies, 14(2), 27-48.

Maoz, I., \& Ellis, D. G. (2006). Facilitating groups in severe conflict: The case of transformational dialogue between Israeli-Jews and Palestinians. In L. Frey (Ed.), Facilitating group communication in context: Innovations and applications with natural groups (pp. 183-203). Cresskill, NJ: Hampton Press.

McHugh, K. (January 10, 2011), Israel ranks highest for time spent on social networking sites. Social-Times (Adweek Network). Retrieved from http://www. adweek.com/socialtimes/israel-ranks-highest-fortime-spent-on-social-networking-sites/66917

Mollov, B. (2006). Results of Israeli and Palestinian student interactions in CMC: An analysis of attitude changes toward conflicting parties. Paper presented at the Annual Conference of the International Communication Association, Dresden, Germany.

Mor, Y., Kligler-Vilenchik, N., \& Maoz, I. (2015). Political expression on Facebook in a context of conflict: Dilemmas and coping strategies of Jewish-Israeli youth. Social Media + Society, 1(2). Retrieved from http://sms.sagepub.com/content/1/2/2056305115 606750.full

Nadler, A. (2004). Intergroup contact and its reduction: A social-psychological perspective. In R. Halabi (Ed.), Israeli and Palestinian identities in dialogue: The School for peace approach (pp. 13-30). New Brunswick, NJ: Rutgers University Press.

Pettigrew, T. F. (1998). Intergroup contact theory. Annual Review of Psychology, 49, 65-85.

Pettigrew, T. F., \& Tropp, L. R. (2006). A meta-analytic test of intergroup contact theory. Journal of Personality and Social Psychology, 90(5), 751-783.

Pettigrew, T. F., \& Tropp, L. R. (2011). When groups meet: The dynamics of intergroup contact. Philadelphia, PA: Psychology Press.

Ron, Y., \& Maoz, I. (2013a). Dangerous stories: Encountering narratives of the other in the IsraeliPalestinian conflict. Peace and Conflict: Journal of Peace Psychology, 19(3), 281-294.
Ron, Y., \& Maoz, I. (2013b). Peacemaking through dialogue? Effects of intergroup dialogue on perceptions regarding the resolution of the IsraeliPalestinian conflict. Dynamics of Asymmetric Conflict, 6(1-3), 75-89.

Ron, Y., Maoz, I., \& Bekerman, Z. (2010). Dialogue and ideology: The effect of continuous involvement in Jewish-Arab dialogue encounters on the ideological perspectives of Israeli-Jews. International Journal of Intercultural Relations, 34(6), 571-579.

Saguy, T., \& Dovidio, J. F. (2013). Insecure status relations shape preferences for the content of intergroup contact. Personality and Social Psychology Bulletin, 39, 1030-1042.

Salomon, G. (2004). A narrative-based view of coexistence education. Journal of Social Issues, 60(2), 273287.

Sherif, M. (1966). In common predicament: Social psychology of intergroup conflict and cooperation. Boston: Houghton-Mifflin.

Sherif, M., Harvey, O. J., White, B. J., Hood, W. R., \& Sherif, C. W. (1961). Intergroup conflict and cooperation: The Robbers Cave experiment (Vol. 10). Norman, OK: University of Oklahoma Press.

Steinberg, S., \& Bar-On, D. (2002). An analysis of the group process in encounters between Jews and Palestinians using a typology for discourse classification. International Journal of Intercultural Relations, 26(2), 199-214.

Stephan, W. G. (2008). Psychological and communication processes associated with intergroup conflict resolution. Small Group Research, 39, 28-41.

Stephan, W. G. (2014). Intergroup anxiety: Theory, research, and practice. Personality and Social Psychology Review, 18(3), 239-255.

Stephan, W. G., \& Stephan, C. W. (2001). Improving intergroup relations. Thousand Oaks, CA: Sage.

Strauss, A., \& Corbin, J. (1998). Basics of qualitative research: Techniques and procedures for developing grounded theory. Thousand Oaks, CA: Sage.

Suleiman, R. (2004a). Jewish-Palestinian relations in Israel: The planned encounter as a microcosm. In $\mathrm{R}$. Halabi (Ed.), Israeli and Palestinian identities in dialogue: The School for peace approach (pp. 31-46). New Brunswick, NJ: Rutgers University Press.

Suleiman, R. (2004b). Planned encounters between Jewish and Palestinian Israelis: A socialpsychological perspective. Journal of Social Issues, 60(2), 323-337.

Tajfel, H., \& Turner, J. C. (1979). An integrative theory of intergroup conflict. In W. G. Austin \& S. Worchel (Eds.), The social psychology of intergroup relations (pp. 33-47). Monterey, CA: Brooks/Cole.

Tajfel, H., \& Turner, J. C. (1986). The social identity theory of intergroup behaviour. In S. Worchel \& W.G Austin (Eds.), Psychology of Intergroup Relations (pp. 7-24). Chicago: Nelson-Hall. 
Walther, J. B., Hoter, E., Ganayem, A., \& Shonfeld, M. (2014). Computer-mediated communication and the reduction of prejudice: A controlled longitudinal field experiment among Jews and Arabs in Israel. Computers in Human Behavior, 52, 550-558.
Wolfsfeld, G., Avraham, E., \& Aburaiya, I. (2000). When prophesy always fails: Israeli press coverage of the Arab minority's Land Day protests. Political Communication, 17(2), 115-131.

\section{About the Authors}

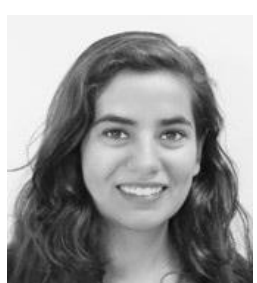

\section{Yifat Mor}

Yifat Mor is a PhD Candidate at the Journalism and Communication department, the Hebrew University in Jerusalem. She has published an article on Israeli-Jewish youths dilemmas and coping strategies regarding political expression on Facebook in the context of the Israeli-Palestinian conflict. Her research interests include Social Media and Politics, New Media, Conflict and Conflict Resolution, Privacy and the Internet.

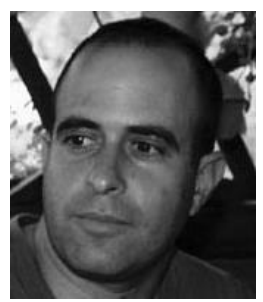

\section{Dr. Yiftach Ron}

Yiftach Ron is a research fellow in the Harry S. Truman Research Institute for the Advancement of Peace at the Hebrew University of Jerusalem. He holds a Ph.D. from the Hebrew University. Dr. Ron has published articles and book chapters on narratives, processes of intergroup dialogue and peacemaking in settings of intractable ethnopolitical conflict. His current research interests include processes of intergroup communication, power relations, discourse, narratives and life stories in conflicted societies, peace education, dialogue, conflict resolution and peacebuilding.

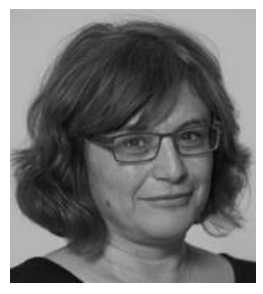

\section{Dr. Ifat Maoz}

Ifat Maoz is a Full Professor, Head of the Department of Communication and Journalism, Head of the Swiss Center and Graduate Program of Conflict Studies and holds the Danny Arnold Chair in Communication. Prof. Maoz is a social psychologist researching psychology and media in conflict and intergroup relations. Her current main interests include psychological, moral and media-related aspects in conflict and peace-making, cognitive processing of social and political information, dynamics of intergroup communication in conflict, and psychological and political processes in the digital age. 